\title{
HUBUNGAN ANTARA KONSEP DIRI DENGAN MINAT BERWIRAUSAHA
}

Jurnal Pendidikan Luar Sekolah

http://kolokium.ppj.unp.ac.id/ Jurusan Pendidikan Luar Sekolah

Fakultas Ilmu Pendidikan

Universitas Negeri Padang

Sumatera Barat, Indonesia

Volume 5, Nomor 2, Oktober 2017 DOI: 10.24036/kolokium-pls.v5i2.30

\author{
Lira Dwita Fitri ${ }^{1,2}$ \\ ${ }^{1}$ Jurusan Pendidikan Luar Sekolah Fakultas Ilmu Pendidikan Universitas Negeri Padang \\ 2Email: liradwitafitri06@gmail.com
}

\begin{abstract}
ABSTRAK
Penelitian ini dilatarbelakangi oleh rendahnya minat berwirausaha lulusan pendidikan kecakapan kerja keterampilan tata busana. Tujuan penelitian ini adalah menggambarkan: (1) konsep diri lulusan pendidikan kecakapan kerja keterampilan tata busana, (2) minat berwirausaha lulusan pendidikan kecakapan kerja keterampilan tata busana, dan (3) hubungan antara konsep diri dengan minat berwirausaha lulusan pendidikan kecakapan kerja keterampilan tata busana. Populasi dalam penelitian ini berjumlah 20 orang, sampel ditarik dari populasi sebanyak $80 \%$. Jadi sampel berjumlah 16 orang lulusan pendidikan kecakapan kerja keterampilan tata busana. Dengan teknik penarikan sampel area random sampling. Teknik pengumpulan data adalah angket dan alat pengumpul data adalah daftar pernyataan tertulis. Teknik analisis data menggunakan perhitungan persentase dan rumus rank order. Hasil penelitian menemukan bahwa (1) konsep diri lulusan pendidikan kecakapan kerja pada keterampilan tata busana rendah, (2) minat berwirausaha lulusan pendidikan kecakapan kerja pada keterampilan tata busana rendah, dan (3) terdapat hubungan yang signifikan antara konsep diri dengan minat berwirausaha lulusan pendidikan kecakapan kerja pada keterampilan tata busana.
\end{abstract}

Kata Kunci: Konsep Diri, Minat Berwirausaha, Pendidikan Kecakaapan Kerja

\section{PENDAHULUAN}

Dasar dari pembangunan manusia bersumber dari pendidikan.Tujuan dari pendidikan adalah untuk meningkatkan kemampuan berpikir, perubahan sikap, dan keterampilan.Pentingnya pendidikan harus dilihat dalam konteks hak asasi manusia, artinya setiap manusia berhak untuk mendapatkan pendidikan. Untuk mencapai tujuan pendidikan diperlukan arah kebijakan yang mantap dengan meningkatkan dan memperluas usaha yang telah dilaksanakan pada bidang pendidikan.

Usaha tersebut dilaksanakan melalui pendidikan formal, informal maupun nonformal. Ketiga jenis pendidikan ini berfungsi mengembangkan kemampuan dan membentuk watak serta peradaban bangsa yang bermartabat dalam rangka mencerdaskan kehidupan bangsa. Melalui ketiga jenis pendidikan diharapkan potensi peserta didik berkembang sehingga menjadi manusia Indonesia yang beriman dan bertaqwa kepada Tuhan Yang Maha Esa.

Pendidikan nonformal merupakan pendidikan yang dilaksanakan di luar sistem persekolahan yang berfungsi sebagai pengganti, penambah, dan pelengkap pendidikan formal. Melihat kelompok sasaran pendidikan nonformal memegang peran untuk 
memberdayakan masyarakat yang kurang beruntung dan juga mereka yang beruntung, para pekerja dan yang belum bekerja. Munculnya masyarakat yang kurang beruntung di satu sisi disebabkan oleh pembangunan ekonomi. Mayoritas masyarakat Indonesia hanya terfokus untuk mencari pekerjaan sebagai pekerja bukan sebagai orang yang mempekerjakan orang lain atau membuka usaha sendiri, padahal sangat banyak peluang yang bisa dimanfaatkan di lingkungan sekitarnya.

Salah satu upaya yang dilakukan pemerintah dalam mengatasi krisis ekonomi adalah dengan meningkatkan sumber daya manusia, yaitu dengan cara memberikan Pendidikan Kecakapan Kerja (PKK). PKK merupakan program pelayanan pendidikan dan pelatihan berorientasi pada pengembangan keterampilan kerja yang diberikan kepada peserta didik agar memiliki kompetensi di bidang keterampilan tertentu setingkat operator dan teknisi yang bersertifikat kompetensi sehingga dapat dijadikan bekal untuk bekerja pada sektor formal sesuai dengan peluang kerja (job opportunities). PKK tidak hanya memberikan kesempatan untuk mendapatkan keterampilan. Namun lebih dari itu, PKK mampu memberikan peluang untuk berwirausaha bagi mereka yang memiliki minat untuk berwirausaha, yang dilaksanakan melalui pendidikan nonformal. Untuk memberikan layanan pendidikan kepada masyarakat perlu dikembangkan suatu program pendidikan luar sekolah.

Salah satu program yang dapat ditemui di masyarakat saat ini adalah program PKK, salah satu kegiatan yang dilakukan pada program ini yaitu keterampilan tata busana yang diselenggarakan oleh pusat Kegiatan Belajar Masyarakat (PKBM) Create Home Kenagarian Kasang Kecamatan Batang Anai, yang merupakan salah satu institusi dari pendidikan nonformal yang memiliki peran penting dan strategis sekali dalam upaya memberdayakan masyarakat.

Kegiatan PKK pada keterampilan tata busana yang disediakan oleh PKBM Create Home ini yakni berlangsung dari tanggal 8 Oktober 2016 sampai 2 Desember 2016, dan yang menjadi warga belajarnya adalah perempuan yang berusia produktif dan bertempat tinggal di Kenagarian Kasang Kecamatan Batang Anai dengan jumlah 20 orang. Keinginan dan tujuan utama yang ingin dicapai dari dilaksanakannya kegiatan ini adalah agar masyarakat memiliki keterampilan yang dapat diandalkan sebagai peningkatan taraf hidup masyarakat agar menjadi lebih baik dari yang sebelumnya.

Berdasarkan pengamatan serta wawancara yang dilakukan oleh peneliti dengan Ibu Suriani selaku pengelola PKBM Create Home, tanggal 10 Januari 2017. Menjelaskan, tujuan diadakannya pendidikan kecakapan kerja pada keterampilan tata busana di PKBM Create Home ini adalah untuk mempersiapkan warga belajar terutama memiliki keterampilan bidang tata busana, dan tujuan lain PKK ini adalah menyiapkan warga belajar menjadi manusia produktif, mampu bekerja mandiri, mengisi lowongan pekerjaan yang ada, dan dunia usaha lainnya. Sesuai dengan tujuan tersebut tidak menutup kemungkinan lulusan PKK pada keterampilan tata busana untuk dapat menciptakan lapangan pekerjaan baru, menciptakan sesuatu yang baru, dan bermanfaat bagi orang banyak. Berdasarkan penuturan Ibu Suriani tersebut, melihat banyaknya praktik yang dijalani selama kegiatan tidak menutup kemungkinan lulusan PKK pada keterampilan tata busana mampu menjadi seorang wirausahawan, hanya saja mereka kurang berminat dengan kegiatan kewirausahaan yang diduga rendahnya keinginan, ketertarikan, dan semangat berwirausaha lulusan pelatihan menjahit. Hal ini terlihat pada saat peneliti melakukan observasi dan wawancara pada tanggal 20 Januari 2017 peneliti memperoleh informasi bahwa, dari 20 orang lulusan program PKK hanya 2 orang yang berwirausaha, 5 orang lulusan PKK pada keterampilan tata busana belum 
mempunyai modal untuk berwirausaha, dan 13 orang lulusan PKK pada keterampilan tata busana lainnya ingin bekerja selain berwirausaha.

Sudarsono (2003), minat merupakan sikap/atau sepenuhnya terlibat dengan suatu kegiatan karena menyadari pentingnya dan bernilai kegiatan tersebut. Menurut Sumantri (2013), minat berwirausaha adalah kecendrungan untuk merasa tertarik, keberanian, serta dapat memenuhi kebutuhan hidup. Rendahnya minat berwirausaha lulusan pelatihan menjahit salah satu diduga konsep diri lulusan pelatihan menjahit yang negatif.

Tujuan penelitian adalah untuk menggambarkan: (1) konsep diri lulusan PKK pada keterampilan tata busana di PKBM Create Home Kengarian Kasang Kecamatan Batang Anai, (2) Minat Berwirausaha lulusan PKK pada keterampilan tata busana di PKBM Create Home Kengarian Kasang Kecamatan Batang Anai, dan (3) hubungan antara konsep diri dengan minat berwirausaha lulusanPendidikan Kecakapan Kerja pada keterampilan tata busana di PKBM Create Home Kengarian Kasang Kecamatan Batang Anai.

\section{METODE}

Penelitian ini termasuk penelitian kuantitatif dengan jenis korelasional. Menurut Arikunto (2005) penelitian korelasional merupakan penelitian yang dimaksudkan untuk mengetahui ada tidaknya hubungan antara dua atau beberapa variabel. Dengan teknik korelasi seorang peneliti dapat mengetahui hubungan variasi dalam sebuah variabel dengan variasi yang lain. Hal ini sejalan dengan pendapat Hanafi (2010), penelitian korelasional bertujuan untuk mengukur tentang ada atau tidak adanya hubungan antara dua atau lebih dari variabel yang diajukan peneliti dengan ukuran-ukuran yang valid dan reliabel.

Populasi dalam penelitian ini berjumlah 20 orang lulusan pendidikan kecakapan kerja keterampilan tata busana. Dalam penelitian ini sampel diambil sebanyak $80 \%$ dari populasi, sehingga sampel pada penelitian berjumlah 16 orang. Penarikan sampel dilakukan dengan caraarea random sampling. Sesuai dengan tujuan penelitian maka sumber data dalam penelitian ini diperoleh dari lulusan pendidikan kecakapan kerja keterampilan tata busana di PKBM Create Home Kenagarian Kasang Kecamatan Batang Anai sebanyak 16 orang. Pengumpulan data mengenai gambaran konsep diri dan minat berwirausaha lulusan pendidikan kecakapan kerja keterampilan tata busana di PKBM Create home Kenagarian Kasang Kecamatan Batang Anai menggunakan teknik pengumpulan data angket dengan alat yang digunakan adalah daftar pernyataan atau kuesioner

Untuk melihat gambaran konsep diri, dan minat berwirausaha lulusan pendidikan kecakapan kerja keterampilan tata busana di PKBM Create Home Kenagarian Kasang Kecamatan Batang Anai, maka digunakan rumus persentase, dan untuk mengetahui hubungan antara variabel $\mathrm{x}$ dan y digunakan teknik rank-order. 


\section{HASIL PENELITIAN DAN PEMBAHASAN}

\section{Hasil Penelitian}

\section{Gambaran Konsep Diri Lulusan}

Skor tentang konsep diri lulusan pendidikan kecakapan kerja keterampilan tata busana di PKBM Create Home diperoleh dengan cara menjumlahkan option yang dipilih oleh lulusan pendidikan kecakapan kerja keterampilan tata busana di PKBM Create Home Masing-masing skor tersebut diperoleh dengan alternatif jawaban Sangat Setuju (SS), Setuju (S), Kurang Setuju (KS), Tidak Setuju (TS).Keseluruhan jumlah item adalah 20 butir item.

Berdasarkan pengolahan data didapat bahwa alternatif jawaban yang tertinggi terdapat pada alternatif jawaban kurang setuju yang dikategorikan rendah dengan skor ratarata $50 \%$ yang terdapat pada jumlah frekuensi 158 dengan jumlah frekuensi ideal 320, alteratif jawaban tidak setuju dengan skor rata-rata $18 \%$ yang diketegorikan sangat rendah, alternatif jawaban setuju dengan skor rata-rata 21\% yang dikategorikan tinggi, dan pada alternatif jawaban sangat setuju dengan skor rata-rata $11 \%$ yang dikategorikan sangat tinggi. Untuk lebih jelasnya hasil dapat dilihat pada histogram di bawah ini.

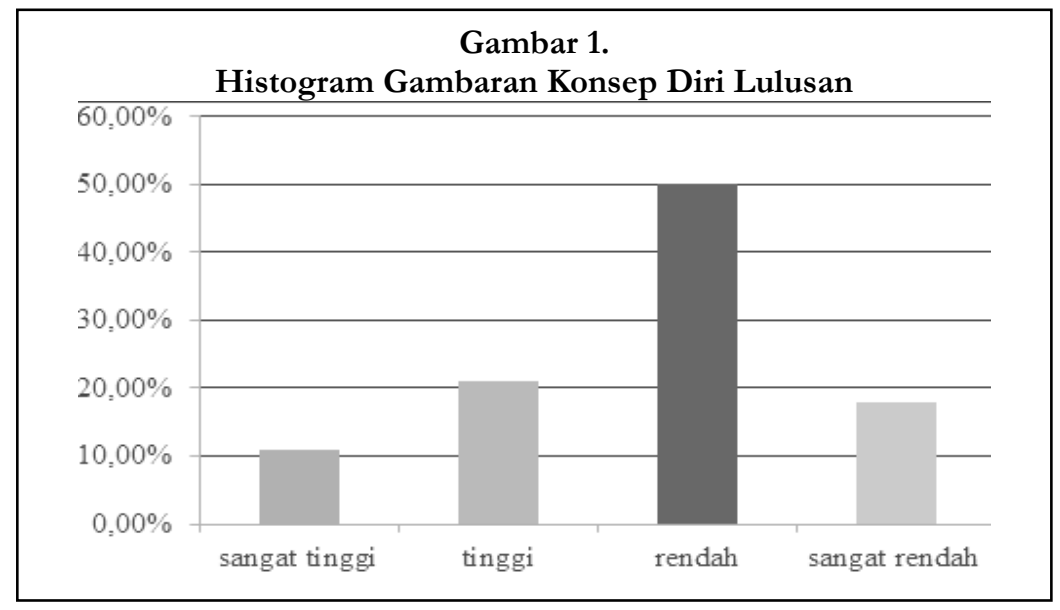

Dari histogram di atas, jelas bahwa alternaatif jawaban tertinggi terdapat pada skor rata-rata 50\% dari 20 item pernyataan responden memiliki konsep diri yang berada pada kategori rendah. Hal ini dibuktikan dengan persentase tertinggi jawaban responden yang memilih kurang setuju yang dikategorikan rendah, persentase tersebut, jauh lebih tinggi dibandingkan persentase jawaban responden pada alternatif jawaban lainnya. Jadi, dapat disimpulkan bahwa konsep diri lulusan pendidikan kecakapan kerja pada keterampilan tata busana di PKBM Create Home Kecamatan Batang Anai, rendah.

\section{Gambaran Minat Berwirausaha Lulusan}

Skor tentang minat berwirausaha Lulusan Pendidikan Kecakapan Kerja Keterampilan Tata Busana di PKBM Create Home Kecamatan Batang Anai diperoleh dengan cara menjumlahkan option yang dipilih warga belajar. Masing-masing skor tersebut diperoleh dengan alternatif jawaban Sangat Setuju (SS), Setuju (S), Kurang Setuju (KS), Tidak Setuju (TS). Keseluruhan jumlah item adalah 22 butir item. 
Berdasarkan pengolahan data didapat bahwa alternatif jawaban yang tertinggi terdapat pada alternatif jawaban kurang setuju yang dikategorikan rendah dengan skor ratarata 52\% yang terdapat pada jumlah frekuensi 181 dengan jumlah frekuensi ideal 352, alteratif jawaban tidak setuju dengan skor rata-rata $21 \%$ yang dikategorikan sangat rendah, alternatif jawaban setuju dengan skor rata-rata 19\% yang dikategorikan tinggi, dan pada alternatif jawaban sangat setuju dengan skor rata-rata $8 \%$ yang dikategorikan sangat tinggi. Untuk lebih jelasnya hasil pengolahan data dapat dilihat pada histogram di bawah ini.

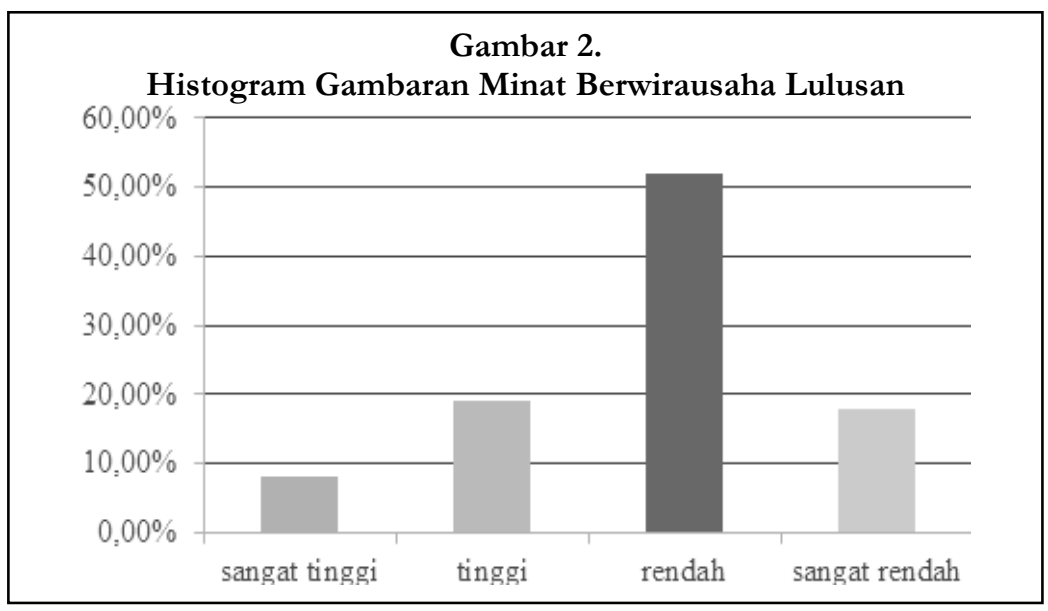

Dari histogram di atas, jelas bahwa alternaatif jawaban tertinggi terdapat pada skor rata-rata $52 \%$ dari 22 item pernyataan, dinyatakan responden memiliki minat berwirausaha yang berada pada kategori rendah. Hal ini dibuktikan dengan persentase tertinggi jawaban responden yang memilih kurang setuju, persentase tersebut, jauh lebih tinggi dibandingkan persentase jawaban responden pada alternatif jawaban lainnya. Jadi, dapat disimpulkan bahwa minat berwirausaha lulusan pendidikan kecakapan kerja keterampilan tata busana di PKBM Create Home Kecamatan Batang Anai, rendah.

\section{Hubungan Konsep Diri dengan Minat Berwirausaha Lulusan}

Salah satu tujuan penelitian ini adalah untuk melihat hubungan antara konsep diri dengan minat berwirausaha lulusan pendidikan kecakapan kerja pada keterampilan tata busana di PKBM Create Home Kecamatan Batang Anai.Untuk mengumpulkan data tersebut, penulis telah menyebarkan angket kepada lulusan pendidikan kecakapan kerja keterampilan tata busana di PKBM Create Home Kecamatan Batang Anai. Setelah melakukan penelitian.

Berdasarkan analisis data didapatkan rhitung $=0.642$ menggunakan rumus rank order sedangkan rtabel pada taraf signifikan $95 \%=0.497$ dan $\mathrm{r}$ tabel pada taraf signifikan $99 \%=$ 0.623 dengan $n=16$. Dengan demikian, dapat dilihat bahwa rhitung $>$ rtabel. Berdasarkan hasil tersebut, maka dapat disimpulkan bahwa terdapat hubungan yang signifikan antara konsep diri dengan minat berwirausaha lulusan pendidikan kecakapan kerja keterampilan tata busana di PKBM Create Home Kecamatan Batang Anai. Dengan demikian, semakin tinggi konsep diri lulusan pendidikan kecakapan kerja keterampilan tata busana, maka akan semakin tinggi pula minat berwirausaha lulusan pendidikan kecakapan kerja keterampilan tata busana. Dan begitu pula sebaliknya, jika konsep diri lulusan pendidikan kecakapan kerja pada 
keterampilan tata busana rendah, maka semakin rendah pula minat berwirausaha lulusan pendidikan kecakapan kerja keterampilan tata busana.

\section{Pembahasan}

\section{Wirausaha Bagian dari Pendidikan Nonformal}

Pernyataan Jhon dalam Sudjana, wirausaha ialah orang yang inovatif, antisipatif, inisiatif, pengambil resiko dan berorientasi laba. Lebih lanjut pendidikan nonformal dapat membina dan mengembangkan kewirausahaan melalui dua pendekatan.Pertama, mengintregasikan materi pembelajaran kewirausahaan ke dalam kurikulum atau program dalam satuan dan jenis pendidikan nonformal (Kurniasih, Lestari, \& Herminingsih, 2011).

Menurut Suryana (2013), mengemukakan 5 indikator ciri-ciri kewirausahaan, yaitu (1) Penuh percaya diri, indikatornya adalah penuh keyakinan, optimis, berkomitmen, disiplin, dan bertanggungjawab; (2) Memiliki inisiatif, indikatornya adalah penuh energi, cekatan dalam bertindak, dan aktif; (3) Memiliki motif berprestasi, berorientasi pada hasil dan wawasan ke depan; (4) Memiliki jiwa kepemimpinan, indikatornya adalah berani tampil beda, dapat dipercaya, dan tangguh dalam bertindak; (5) Berani mengambil risiko dengan penuh perhitungan, dan oleh karena itu menyukai tantangan.

Kewirausahaan erat kaitannya dengan konsep pendidikan luar sekolah. Menurut Joesoef (dalam Aini, 2006) menyatakan bahwa salah satu sasaran PLS berdasarkan segi pelembagaan program di mana keseluruhan proses pengintegrasian antara program pendidikan luar sekolah dan pembangunan masyarakat. Sesuai dengan sasaran PLS yaitu pembangunan masyarakat upaya yang dapat dilakukan adalah meningkatkan SDM. Untuk meningkatkan kualitas sumber daya manusia bisa dilakukan dengan cara berwirausaha.

Berwirausaha tidak hanya dapat dilakukan sebagai kiat-kiat bisnis jangka pendek, tetapi juga sebagai kiat untuk bertahan hidup secara umum dalam jangka panjang sehingga mencapai suatu kesejahteraan. Sesuai dengan tujuan PLS yaitu untuk mensejahterahkan masyarakat, maka salah satunya yaitu dengan cara keterampilan berwirausaha dengan memanfaatkan peluang yang ada di sekitar masyarakat itu sendiri, agar permasalahan ekonomi dan pengangguran di Indonesia ini bisa teratasi.

\section{Konsep Diri Lulusan}

Konsep diri merupakan bagian yang terpenting dalam kepribadian seseorang. Konsep diri adalah ciri khas yang membedakan setiap individu dengan individu yang lainnya. Temuan penelitian ini menunjukkan bahwa gambaran konsep diri lulusan pendidikan kecakapan kerja keterampilan tata busana di PKBM Create Home ditinjau dari konsep diri secara fisik meliputi konsep diri materi, konsep diri bentuk tubuh, dan konsep diri secara psikis meliputi konsep diri sosial, konsep diri emosional, konsep diri moral dan konsep diri kognitif lulusan pendidikan kecakapan kerja keterampilan tata busana di PKBM Create Home Kecamatan Batang Anai, terlihat rendah. Hal ini dapat dilihat secara rinci pada aspek jawaban responden bahwa sebagian besar responden menyatakan kurang setuju pada aspek konsep diri. Hal ini menunjukkan bahwa secara umum lulusan pendidikan kecakapan kerja keterampilan tata busana di PKBM Create Home belum memiliki keyakinan diri untuk bisa melakukan kegiatan kewirausahaan.

Oleh karena itu konsep diri lulusan pendidikan kecakapan kerja keterampilan tata busana perlu ditingkatkan agar dapat mempersiapkan diri dalam menghadapi tantangan 
kehidupan di masa yang akan datang, siap bersaing di dunia kerja serta mencapai tujuan akhirnya dengan keyakinan diri yang tinggi. Tinggi dan rendahnya konsep diri dapat menentukan minat seseorang. Orang yang memiliki konsep diri, memiliki keyakinan untuk menjadi sukses lebih tinggi dari pada orang yang memiliki konsep diri rendah. Konsep diri adalah keyakinan dan penilaian seseorang terhadap dirinya bahwa ia mampu melakukan tugas tertentu dengan baik. Konsep diri memiliki keefektifan, yaitu individu mampu menilai dirinya memiliki kekuatan untuk menghasilkan pengaruh yang diinginkan. Tingginya konsep diri yang dipersepsikan akan memotivasi individu secara kognitif untuk bertindak lebih tepat dan terarah, terutama apabila tujuan yang hendak dicapai merupakan tujuan yang jelas.

Menurut pendapat Eptein (dalam Mudjiran Dkk (2007)) menjelaskan bahwa konsep diri adalah pendapat, perasaan atau gambaran seseorang tentang dirinya sendiri yang menyangkut fisik (materi dan bentuk tubuh) maupun psikis (sosial, emosional, moral, dan kognitif). Hal ini menunjukkan bahwa secara umum lulusan pendidikan kecakapan kerja pada keterampilan tata busana belum memiliki kepercayaan dan keyakinan diri untuk bisa melakukan kegiatan kewirausahaan. Oleh karena itu konsep diri lulusan pendidikan kecakapan kerja keterampilan tata busana di PKBM Create Home perlu ditingkatkan agar dapat mempersiapkan diri dalam menghadapi tantangan kehidupan dimasa yang akan datang, siap bersaing di dunia kerja serta mencapai tujuan akhirnya dengan keyakinan diri yang tinggi.

Tinggi dan rendahnya konsep diri dapat menentukan minat seseorang. Orang yang memiliki konsep diri, memiliki keyakinan untuk menjadi sukses lebih tinggi dari pada orang yang memiliki konsep diri rendah. Manusia yang yakin bahwa mereka dapat melakukan sesuatu yang mempunyai potensi untuk dapat mengubah kejadian di lingkungannya, akan lebih mungkin untuk bertindak dan lebih mungkin untuk menjadi sukses dari pada manusia yang mempunyai konsep diri rendah.

Hasil penelitian di atas menunjukkan bahwa konsep diri merupakan tanggapan atau anggapan seseorang tentang dirinya. Hal ini sesuai dengan pendapat Sunaryo (dalam Saputri \& Moordiningsih, 2016) yang menyatakan bahwa konsep diri adalah cara individu dalam melihat pribadi secara utuh, menyangkut fisik, emosi, intelektual, sosial dan spiritual, termasuk di dalamnya persepsi individu dengan orang lain maupun lingkungannya.

Menurut Burns (dalam Ghufron \& Risnawita, 2010), konsep diri merupakan kesan terhadap diri sendiri secara keseluruhan yang pendapatnya terhadap diri sendiri, pendapat tentang gambaran diri dimata orang lain, dan pendapatnya tentang hal-hal yang dicapainya. Selain itu, Atwater (dalam Prayitno, 2006) juga mengemukakan bahwa konsep diri pada dasarnya mengandung arti keseluruhan gambaran dia sendiri yang meliputi persepsi, perasaan, keyakinan dan penilaian diri orang itu tentang dirinya.

Terkait dengan minat berwirausaha, Ghufron \& Risnawita (2010) mengatakan bahwa konsep diri adalah kesadaran serta penilaian seseorang mengenai diri sendiri yang merupakan gabungan dari keyakinan terhadap bentuk fisik, psikologis, sosial, emosional, aspiratif, dan prestasi yang dicapai, termasuk minat berwirausaha. Menurut Mudjiran Dkk (2007), juga menjelaskan bahwa konsep diri merupakan pandangan seseorang tentang dirinya, berdasarkan pandangan atau penilaian orang lain terhadap dirinya. Oleh karena itu, dapat disimpulkan bahwa semakin tinggi tingkat konsep diri seseorang terhadap dunia bisnis, akan semakin kuat minat berwirausahanya. Dengan kata lain, ketika seseorang akan membuka bisnis baru, diperlukan keyakinan diri bahwa dirinya mampu menjalani seluruh aktivitas bisnis agar usahanya dapat berhasil. 
Dari penjelasan di atas dapat dilihat bahwa konsep diri mempunyai peranan penting dalam menentukan keberhasilan seseorang. Konsep diri merupakan hasil persepsi diri sendiri dan dari pengalaman. Hal ini sesuai dengan pendapat Desmita (dalam Ananda \& Sawitri, 2015), menjelaskan konsep diri adalah gagasan tentang diri sendiri yang mencakup keyakinan, pandangan dan penilaian seseorang terhadap dirinya sendiri. Oleh karena itu, dapat disimpulkan bahwa semakin tinggi tingkat konsep diri seseorang terhadap dunia bisnis, akan semakin kuat minat berwirausahanya. Dengan kata lain, ketika seseorang akan membuka bisnis baru, diperlukan keyakinan diri bahwa dirinya mampu menjalani seluruh aktivitas bisnis agar usahanya dapat berhasil.

Hasil penelitian menunjukkan bahwa lulusan pendidikan kecakapan kerja keterampilan tata busana di PKBM Create Home Kecamatan Batang Anai memiliki konsep diri yang rendah. Berdasarkan pendapat tersebut jelas bahwa konsep diri akan memengaruhi tindakan yang akan dipilih oleh seseorang. Salah satu tindakan yang dipilih seseorang adalah untuk berkeinginan menjadi wirausahawan.

\section{Minat Berwirausaha Lulusan}

Minat berwirausaha tidak dibawa sejak lahir tapi tumbuh dan berkembang sesuai dengan faktor-faktor yang memengaruhi. Faktor yang memengaruhi tumbuhnya keputusan untuk berwirausaha merupakan hasil interaksi dari beberapa faktor yaitu karakter kepribadian seseorang dan lingkungannya.

Fuadi (dalam Kurniawan, Khafid, \& Pujiati, 2016), minat berwirausaha adalah keinginan, ketertarikan, serta kesediaan untuk bekerja keras atau berkemauan keras untuk berusaha secara maksimal untuk memenuhi kebutuhan tanpa merasa takut akan apa yang terjadi dan berdasarkan temuan peneliti dan pengolahan data tentang minat berwirausaha lulusan pendidikan kecakapan kerja keterampilan tata busana di PKBM Create Home Kenagarian Kasang Kecamatan Batang Anai. Dari aspek tersebut dapat dilihat bahwa minat berwirausaha lulusan pendidikan kecakapan kerja cendrung masih rendah, dilihat secara rinci pada aspek jawaban responden yang memberikan kurang setuju. Artinya sebagian besar lulusan pendidikan kecakapan kerja keterampilan tata busana di PKBM Create Home belum mempunyai minat berwirausaha dalam mengikuti pendidikan kecakapan kerja keterampilan tata busana di PKBM Create Home Kenagarian Kasang Kecamatan Batang Anai.

Slameto (2013), berpendapat bahwa minat adalah suatu rasa lebih suka dan rasa ketertarikan pada suatu hal atau aktivitas, tanpa ada yang menyuruh. Minat pada dasarnya adalah penerimaan akan suatu hubungan antara diri sendiri dengan sesuatu di luar diri. Semakin kuat atau dekat hubungan tersebut, semakin besar minat.

Gunarsa (dalam Amini \& Nurtjahjanti, 2016) mengatakan minat merupakan sesuatu yang pribadi dan berhubungan erat dengan sikap. Minat berwirausaha dari seseorang yang tumbuh akan diikuti dengan sikap seseorang yang menjurus pada segala sesuatu yang berkaitan dengan wirausaha. Pengertian tersebut, memberikan pemahaman tentang minat berwirausaha merupakan suatu kesediaan jiwa atau timbul keinginan emosi yang sifatnya aktif, tetap dan selalu muncul keinginan untuk menerima dan atau melaksanakan aktifitas yang diekspresikan dengan perasaan senang/tidak senang pada obyek atau aktifitas yang bersangkutan.

Susanto (dalam Siswadi, 2013), minat akan selalu terkait dengan persoalan kebutuhan dan keinginan. Sebab minat berpengaruh dan berfungsi dalam pemenuhan kebutuhan. 
Sehingga dengan demikian, semakin kuat kebutuhan sesuatu maka akan semakin besar juga minat terhadap kebutuhan tersebut. Keinginan tersebut berupa, kebutuhan untuk berwirausaha yang bisa dilakukan oleh lulusan pendidikan kecakapan kerja dalam setelah mengikuti pendidikan kecakapan kerja keterampilan tata busana di PKBM Create Home.

Secara umum minat menurut Djaali (2011), adalah rasa lebih suka dan rasa ketertarikan pada suatu hal atau aktifitas, tanpa ada yang menyuruh. Seseorang yang berminat terhadap suatu aktivitas akan memeperhatikan aktivitas itu secara konsisten dengan rasa senang. Minat berpengaruh dan berfungsi dalam pemenuhan kebutuhan. Sehingga dengan demikian, semakin kuat kebutuhan sesuatu maka akan semakin besar juga minat terhadap kebutuhan tersebut. Keinginan tersebut berupa, kebutuhan untuk berwirausaha yang bisa dilakukan oleh lulusan pendidikan kecakapan kerja pada keterampilan tata busana. Wirausaha memberikan peluang untuk menciptakan pemenuhan kebutuhan bagi individu. Terkhusus pemenuhan kebutuhan di bidang ekonomi. Namun di luar dari semua itu minat tidak hanya bicara soal kebutuhan namun juga ketertarikan dan keberanian. Dari pendapat di atas dapat disimpulkan bahwa minat berwirausaha adalah, kecendrungan lulusan pendidikan kecakapan kerja pada keterampilan tata busana yang berupa sifat tertarik, berani dan butuh akan sebuah objek atau kegiatan. Minat tersebut tumbuh tanpa adanya paksaan yang mengharuskan individu tersebut untuk melaksanakan suatu kegiatan.

Dari pendapat di atas dapat disimpulkan bahwa minat berwirausaha adalah, kecenderungan lulusan pendidikan kecakapan kerja keterampilan tata busana di PKBM Create Home yang berupa sifat tertarik, berani dan butuh akan sebuah objek atau kegiatan. Minat tersebut tumbuh tanpa adanya paksaan yang mengharuskan lulusan pendidikan kecakapan kerja keterampilan tata busana di PKBM Create Home tersebut untuk melaksanakan suatu kegiatan. Berdasarkan penjelasan di atas dapat disimpulkan seseorang yang mempunyai konsep diri yang tinggi menunjukkan minat berwirausaha yang tinggi, sebaliknya seseorang yang mempunyai konsep diri yang rendah maka seseorang terrsebut juga tidak akan berminat dalam berwirausaha.

\section{KESIMPULAN}

Berdasakan hasil penelitian dan pembahasan tentang hubungan antara konsep diri dengan minat berwirausaha lulusan pendidikan kecakapan kerja pada keterampilan tata busana di PKBM Create Home Kecamatan Batang Anai, diperoleh kesimpulan sebagai berikut: (1) konsep diri lulusan pendidikan kecakapan kerja rendah, hal ini disebabkan karena faktor konsep diri secara fisik yang meliputi konsep diri materi, konsep diri bentuk tubuh dan konsep diri secara psikis meliputi konsep diri sosial, konsep diri moral, konsep diri emosional, dan konsep diri kognitif yang dimiliki lulusan pendidikan kecakapan kerja di PKBM Create Home yang negatif terhadap konsep dirinya yang dikategorikan rendah, (2) Minat berwirausaha lulusan pendidikan kecakapan kerja keterampilan tata busana rendah, hal ini disebabkan karena lulusan pendidikan kecakapan kerja keterampilan tata busana kurang tertarik untuk berwirausaha, kurang menyenangi wirausaha, serta kurang berkeinginan untuk berwirausaha, dan (3) Terdapat hubungan yang signifikan antara konsep diri dengan minat berwirausaha lulusan pendidikan kecakapan kerja keterampilan tata busana di PKBM Create Home Kecamatan Batang Anai. Jadi dapat disimpulkan bahwa jika konsep diri lulusan pendidikan kecakapan kerja keterampilan tata busana rendah maka minat berwirausaha lulusan pendidikan kecakapan kerja pada keterampilan tata busana rendah. Namun sebaliknya 
jika konsep diri lulusan pendidikan kecakapan kerja pada keterampilan tata busana tinggi maka semakin tinggi minat berwirausaha lulusan pendidikan kecakapan kerja pada keterampilan tata busana.

\section{DAFTAR RUJUKAN}

Aini, W. (2006). Konsep Pendidikan Luar Sekolah (Buku Ajar). UNP: PLS FIP.

Amini, D. S., \& Nurtjahjanti, H. (2016). Konformitas dan Minat Berwirausaha pada Mahasiswa Jurusan Administrsi Bisnis Fakultas Ilmu Sosial dan Ilmu Politik Universitas Diponegoro. Empati, 5(1), 96-101.

Ananda, D. R. T., \& Sawitri, D. R. (2015). Konsep Diri ditinjau dari Dukungan Teman Sebaya pada Remaja di Panti Asuhan Qosim Al-Hadi Semarang. Empati, 4(4), 298-303.

Arikunto, S. (2005). Manajemen Penelitian. Jakarta: Rineka Cipta.

Djaali. (2011). Psikologi Pendidikan. Jakarta: PT Bumi Aksara.

Ghufron, \& Risnawita, R. (2010). Teori- Teori Psikologi. Yogyakarta: Ar-Ruzz Media. Hanafi, A. H. (2010). Metodologi Penelitian Kependidikan. Batusangkar: STAIN Press.

Kurniasih, A., Lestari, S. D., \& Herminingsih, A. (2011). Persepsi Mahasiswa Terhadap Kuliah Kewirausahaan dan Pengaruhnya Terhadap Sikap dan Intensi Berwirausaha Mahasiswa (Studi Komparatif Antara UBL VS UMB Jakarta). Jurnal Ilmu Ekonomi Dan Sosial, 2(2), 129-146.

Kurniawan, A., Khafid, M., \& Pujiati, A. (2016). Pengaruh Lingkungan Keluarga, Motivasi, dan Kepribadian Terhadap Minat Wirausaha Melalui Self Efficacy. Journal of Economic Education, 5(1), 100-109.

Mudjiran dkk. (2007). Perkembangan Peserta Didik. Padang: UNP Press.

Prayitno, E. (2006). Psikologi Perkembangan Remaja. Padang: BK FIP UNP.

Saputri, M. E., \& Moordiningsih. (2016). Pembentukan Konsep Diri Remaja pada Keluarga Jawa yang Beragama Islam. Jurnal Ilmiah Psikologi Terapan, 04(02), 261. https://doi.org/10.5151/cidi2017-060

Siswadi, Y. (2013). Analisis Faktor Internal, Faktor Eksternal dan Pembelajaran Kewirausahaan yang Memengaruhi Minat Mahasiswa dalam Berwirausaha. Jurnal Manajemen \& Bisnis, 1(01), 1-17. https://doi.org/10.1017/CBO9781107415324.004

Slameto. (2013). Belajar dan Faktor-Faktor Yang Memengarubi. Jakarta: Rineka Cipta.

Sudarsono, J. (2003). Menumbubkan Minat Belajar Untuk Mencapai Sukses dalam Studi. Jakarta: Erlangga.

Sumantri, D. (2013). Pengaruh Faktor Aspirasi Pekerjaan dan Aspirasi Jurusan Terhadap Kematangan Karir Siswa SMK Jurusan Otomotif di DIY 2012/2013. Universitas Negeri Yogyakarta. 